\title{
Interview with Jan Dušek \\ (13. 2. 2018)
}

Vlasta Koubská

Prof. Jan Dušek is the head of the Department of Stage Design at DAMU (Theatre Faculty of the Academy of Performing Arts in Prague). As a stage designer he worked on more than 500 productions. He collaborates with Czech theatres as well as with theatres in Germany, Poland and the US. His designs were exhibited numerous times, winning many prizes and awards (Biennial Novi Sad 1974, Alfréd Radok Award 1996). His colleague from the Department of Stage Design Vlasta Koubská interviewed Dušek and discussed with him his designs for Shakespearean productions.

[VK] Professor Dušek, you designed sets and costumes for an impressive thirty-eight productions of Shakespeare, which is a significant number. Is there a play you have developed a special attachment to? Can one even say that?

[JD] Yes, I think it's Hamlet. I have done it, I think, six times.

[VK] According to my list, you designed it five times in Czech theatres...

[JD] Yes, and I also did it in Baden Baden at the end of the 1980s with the director Miška.

[VK] Why this play in particular?

[JD] I am proud that two Hamlets are never alike. Hamlet is, in my opinion, very bound to the time and the place, in which it is being staged. Thus, one must respond to the current situation. Hamlet is not a common text, it's an existential play and, properly done, Hamlet should cause a scandal. I managed to do that twice.

[VK] Which were the two scandalous Hamlets?

[JD] The first scandal was of course at the Theatre on the Balustrade (1978) and a partial scandal was in Baden Baden.

I would like to speak about the one at the Balustrade. On the one hand, the strong reception was due to Schorm's exceptional direction, on the other hand, because we performed the so-called first quarto (1603), with different names such as Corambis instead of Claudius etc. Although I have been doing Hamlet for years, I've always had one key approach: I've always read the text again, as if I didn't know it. Reading the first quarto in Lukeš' translation was a little easier, because the text is different. It was simply about 
reading the text with a complete lack of bias, as if I was reading it for the first time, working only with the text and nothing else. When I read it at the time of this production, I was captivated by a phrase, which became my inspiration, 'Why such daily cast of brazen cannon?' - and this was during a time of 'permanent struggle for peace', during which arms were produced non-stop. And a second sentence: 'The funeral bak'd-meats did coldly furnish forth the marriage table', which for me was crucial.

\section{[VK] The key to the stage and the costumes?}

[JD] With the help of the costumes, I wanted to make Elsinore an organised society. To develop this was fairly complicated. I really did sketch some costumes, took them to the seamstresses and the head seamstress said: 'This is out of our league.' Because I knew why I wanted to do it and how, I couldn't be stopped by their lack of work-hours or capacity. I received the orders in the office and set out to Prague (to the city centre). At the end of Celetná street was a clothing store and they were selling clothes, which were then called 'safari'. I dressed the whole of Elsinore in it, I dyed the costume of Olda Vlach as Hamlet black, in order to provoke with the sadness. The seamstresses sewed mainly Elizabethan costumes for the performances of the actors, which were, in the details, really historical costumes.

\section{[VK] And how was it with the famous Gravediggers scene?}

[JD] As I read the scene with the Gravediggers, it says there that 'a scull hath bin here this dozen yeare'. Every time I saw images of Hamlet with a clean skull, as if it had been borrowed from the natural history office, it did not do the trick. To kiss it, it has to be disgusting, only then could the intense relationship be seen. So, it was a skull covered in soil with hair and when he kissed it, people's stomachs turned. In it the relationship emerged. At that time, and it was very unprofessional, I had only those costumes sewn about which I knew for sure how they should look. And I've always watched it onstage, for example a bigger part of the cast was in rehearsal clothes and suddenly came someone in finished costume, and then I confronted it. And that was extremely entertaining work because I was looking for mistakes in it, correcting it and so on. The system was good, but a big professional theatre does not allow it. Also, in response to my emphasis on the militarism within the play and our own 'permanent struggle for peace' above the whole space a military net was hung and everybody was asking why it was there; but they only got to know it in the finale. There also was no possibility to have a trap door, so we have built the grave from ammunition boxes, which were painted in military camouflage.

I had a problem with the grave-diggers: We had an agreement with Schorm that they would be clowns. Zedníček and Bedrna [the actors playing the gravediggers] rehearsed with red noses; but what to do with it? I still did not know what to do with it. But then, when I saw what the skull would look like, I realized that it was an exhumation. As a child, I did see an exhumation. So, I went to Řempo (short for řemeslné potřeby, crafting tools) in Dlouhá Street and bought rubber aprons, I bought big rubber gloves and received big rubber work boots. And they as grave-diggers also received those big hats, which was a joke of mine, because those were worn by the technical staff of the 
National Theatre. So, this is how I dressed them up: they had shorts, bare legs, the rubber boots and that was how I sent them onstage. I ran through the foyer and stood behind [the director] Schorm and I was watching him and his reactions. I really loved these games between us. He came, did not say anything and rehearsed only the finale and suddenly he said to Zedníček: Pavel, please, tell Sedlák, who was a prop-man, to give you a bag of flour and some sandwiches. So, Sedlák gave him that and Schorm had all the 'corpses' brought onstage, including Ophelia, whilst the grave-diggers were singing to themselves. Then came Zedníček with that bag of flour and that sandwich. He was singing to himself, with one hand he ate his sandwich and with the other he was sprinkling the corpses with the flour, to represent chlorinated lime. The première was indeed scandalous, only one review by Kliment in Rudé Právo [Red Justice] could be published, where only the numbers of the crime sections and penalties were missing. And then we went to Berlin to give two performances at the Deutsches Theater. The first performance was mostly for the official guests, meaning embassies, their Ministry of Culture, etc. For the first half of the performance, I was upstairs in the corridor (there was a problem with the construction and with the Fire Department) and from the intercom I could hear and feel a draught, which was blowing from the auditorium on the stage. That kind of snigger: What are these Czechs showing us? But they, when they started to snigger, underestimated one thing. Because the reactions had to escalate, the first shock - that was a Grand Guignol: The killing of Polonius, when Hamlet stabbed him, a bloody leak appeared and Přeučil fell out of it. By then the audience were kind of shrieking. And I said to myself, I can't miss this. I was sitting in the auditorium during the second half, next to me sat an elderly genteel lady. And when the grave-digger scene with the chlorinated lime came, even the Germans were screaming their heads off. They already understood. And then it was over and there was booing! But it turned out that one half of the auditorium booed and the other half shouted 'Bravo!'.

I then gave the actors' dark eye make-up. And next to me was now sitting this elderly lady and when the booing started, she suddenly cried out 'Nein! Bravo!'. She raised her hand and punched me with her elbow in my eye. She apologized but I still went home with a black eye and looked just like the actors with their make-up.

I have never seen Schorm so happy. When we looked out of the dressing rooms, we could see the square in front of the Deutsches Theater. And there stood groups of people, talking and shaking hands with each other. And then Schorm said: 'Honzík, we will have to leave this place with a police escort'. He was over the moon. An official banquet followed, with German acting colleagues. I had a friend there, a wife of Jiří Vrštala, Angelica Demröse, and she was late and said: I listened to the Deutsche Welle and they say that this was the theatrical event of the season in Berlin. So, the atmosphere changed and the second day the theatre was packed!

[VK] Did the scenography function similarly in that large space?

[JD] It didn't matter at all. On the Balustrade all of the scenes were done in a way (not intentionally), that worked on a large stage as well as on a small one, basically anywhere. 
[VK] How exactly did the drapes hanging in the background work?

[JD] They were primarily used for spying, snooping and at the same time it was a wedding, and behind it was the mourning, the funeral.

[VK] The actor Vlach was in fact a bit of an antihero, he was not a priori a hero, who wins the favor of the audience. Bartoška played Corambis.

[JD] There was a great moment when Hamlet utters the text about himself being supposed to rule and that he is actually not so young and then he took his rolls of fat on his stomach between his fingers. And that was exactly it!

\section{[VK] And with respects to your other Hamlets?}

[JD] The first Hamlet was in Petr Bezruč Theatre in Ostrava (1970). There were two Hamlets: Jan Vlasák and Jirka Wimmer, they were great and it really was a scandal. The scandal was for example in the fact, that Hamlet had a book onstage, and as the dialogue was spoken, he was tearing the pages from the book and wiping his bottom. People were about to go crazy. The biggest heckler from all the Hamlets I have ever done was Jirka Wimmer. Vlasák was a bit more restrained. But Wimmer's provocations, they irritated people a lot.

[VK] Was this the first time the distinctive costume of a mummy for the character of Hamlet's father's Ghost appeared?

[JD] This is because of how literal I am. When I saw the ghost of Hamlet's father for example in Svoboda's Hamlet (directed by Pleskot in 1959), there were two spotlights and a speaking computer voice, which was transmitted by a loudspeaker; and I thought, oh my God, that's not the way it was meant to be! This is a daddy, it's not light and sound from a loudspeaker. So that's why I again did it literally: He had those sores from being poisoned and because he was dead, he was wrapped in rags. Also, there was a moment in a rusty armour, which was creaking. He was at the same time a bit ridiculous, as fathers always are.

[VK] And Hamlet eventually becomes this ludicrous father? Draped in a beautiful decorative cloak.

[JD] Yes, we all become our parents. It's horrible... It's like the realisation that although I wanted to be a lot of things in my life, I knew that I wanted to be everything except what my ancestors had been. I knew that I wouldn't be a teacher or a clerk; but when I became Dean of DAMU (the Academy of Performing Arts in Prague), I was both: a teacher and a clerk.

[VK] Talking about Evald Schorm, we cannot omit Macbeth in the Theatre on the Balustrade (1981). Am I reading it correctly that behind it is an inspiration by Zelenka's Protée?

[JD] Everything I do has Zelenka in the background. Tröster [Jan Dušek's teacher] helped me to discover him. But there is also something else. I used to subscribe to the magazine called Hobby. I had an issue dealing with photography. And one part was 
about sports photography. And there were two weirdly dressed men, two wrestlers. I don't like weapons, if there should be violence, then it should be a clean fight using hands only. And from this the idea of using kimonos emerged, precisely from this photo.

[VK] So more of a physical fight than intrigues...

[JD] Exactly; the coarseness. That is exactly why there were those mats, at the beginning it was a place for a fight and then they became Birnam Forest...

[VK] The witches wore stockings over their faces, were they supposed to look like robbers?

[JD] Yeah, a bit, but on the stockings they also had a beard attached. It originated from the fact that they had to perform someone else immediately afterwards, so they needed to change quickly... at the same time they did not have a face or the face was deformed. A scene of the feast was beautiful too, as Macbeth is the only one to see the shattered, bloody, murdered Banquo [performed by Mrkvička], the others do not see him. That's the joke. The others are saying 'Why is the king acting mad?'; because he is the only one to see, the horrible thing that has happened. The literalness was also important there.

[VK] The core idea of Macbeth was to bring Macbeth's head onstage but you eventually executed this idea differently in the production, right?

[JD] We sat in Krkonošská street and the dramaturg Vondráček came up with the idea that they would record the interview about the concept. We all came there, Lukeš was there, the tape recorder was there, Vondráček was there, me and Schorm; and Schorm started to talk about problems that he was having with his teeth... and then suddenly he said: 'Hey, there should be Macbeth's head brought onstage, I suppose this is stupid?' And I said: 'Well, it is stupid. It is always funny onstage, it would rather fit some Gozzi [the C18th Italian playwright and defender of the Commedia dell'Arte]. But what if we carried our Macbeth [Bartoška] onstage like a captured dead animal on a stick? Perhaps hang him like Mussolini.' And all of a sudden Schorm said: 'Yeah! And Jana Preissová like Petacci!' So, we talked some more and then Lukeš said: 'Well now we should start talking about the concept.' He pressed the record button, there was silence for a while... and then Schorm said: 'My dear, we already have a deal.' The whole concept was based on this situation.

[VK] That was also the first time that a review appeared which said that your scenography is based on the fact that spectators hear something but see something completely different.

[JD] Yes, it still works.

[VK] Do you think that the form you use is always up to date?

[JD] It should be. But I don't know what's called 'the trends in scenography'. Or else, I know that there are still box sets being designed because the audience is used to it and it works but it's hard to say how long this form will last. There are always forms, 
which are used at a given time and period. Káta [Věra] Ptáčková for example used to say, that we live in a time of tunnels. But those are the things that don't really interest me. I always begin with some key situation. I am rather based on detail, I usually begin with some key situation and then everything is based on that situation. Not at all from some a priori concept. I always focus more on the production than on the visual. And this is what I try to teach my students.

[VK] You created more than fifty productions with the director Oto Ševčik, eight of which were Shakespeare texts. In 1976, you staged Twelfth Night. There were three carriages onstage, which were at the same time a stage with arches and had many other meanings. How did your cooperation function, was it a dialogue?

[JD] No, there was no dialogue. Both Ota and especially Schorm were great in picking up the threads. Similarly, as with the grave-diggers by Schorm, let's say I somehow spurred them on, I had some idea and they gave it the meaning; cooperation, it is important, you can't do it otherwise.

\section{[VK] How did Coriolanus directed by O. Ševčík (1979) look?}

[JD] There we used strips of textile, which nevertheless did not behave like rags, then there were three segments that were both walls, fortified lines, grandstands, barricades and all, on the walls where the battles happened. That really was a fortunate solution. We used hard front lighting, thanks to the firm textiles, which could not be shone through. The strips of the textile also changed their function: they were transformed by the blood stains from civil wars, they changed into banners, women embroidered them at home. Rags that do not behave like rags, such canvases, which don't create any curtains. I don't like loose and pleated drapes. This solution at the same time allowed quick entrances. The front staircase led from the orchestra pit and therefore lengthened the stage. I liked this production, I think it turned out well.

[VK] A Midsummer Night's Dream (1983) was also created together with O. Ševčík.

[JD] I gladly remember this show. When the Grand Theatre in Pilsen was closed for reconstruction, it was done in Alfa Theatre. It is a space, where the stage is small but the space of the theatre is beautiful. I needed to get Titania [J. Tesařová] into another dimension. I had a very supporting net made and hanged it between the steel construction in the auditorium above the spectators. The whole performance begins with Puck jumping from above into this net. The spectators were screaming with horror because they did not perceive the net, they saw a man falling on them. That was a huge effect. Puck was played by an older, conscientious actor [T. Šolc], and we came to the dress rehearsal. As the net was ready, he pulled the ends of the net at the fastening and the net fell into his hands. It turned out that someone caught the strings between the gate of the carabiner and not steadily around it. That was a common sabotage. It was investigated by the police, it seemed that maybe someone wanted to kill the actor. If he fell into the crowd from 
a height of four meters... After that it was always very carefully checked. There was only a thick polyurethane foam carpet onstage and when the lovers walked on it, it created waves and similar effects. I am ashamed to admit, how the effect of the nets came into existence. When I received a scholarship to study in Paris [in 1969] I used to go to a certain literary club. Many years later, I came to Paris and instead of a very progressive literary club there was a porn club. And there were people drinking, eating and above them in the nets...

[VK] Before that, you did your first A Midsummer Night's Dream in the State Theatre in Brno (1977) with P. Hradil.

[JD] I really liked this production, even though there was a big problem. What to do in this huge space with this play? And again, I created such inclined risers. We needed to make the huge fourteen-meter wide proscenium homely. We decided to use Mendelssohn and an orchestra. So, the orchestra was creating the stage design. The musicians were sitting and playing at the end of the inclined risers, three meters high, that was good. There were ropes hanging from the inclined ceiling. There was a great Puck, the excellent Mr. Karlík. Puck was supposed to fly from one side of the stage to the other, with an overall distance of about eight meters. His entrance was phenomenal. He swung on the rope from one side to the other, jumped on the top of the inclined riser, used it as a slide, got up, did a somersault and continued. Incredible! People were excited... At the same time, he did it sort of lazily. Lazy, tired, old Puck. He did that many times and was really excellent.

[VK] From the collaboration with the director Černín a very interesting production of Othello (1996) originated. You had used the principle of silhouettes long before; but here, the silhouettes were very effectively used for making the production dynamic.

[JD] In Othello, I needed quick changes, there were different screens moving around and giving the performance new configurations. Something is happening onstage, it is the end of a scene and actually a set for another scene is already being built. I wanted to make everything faster.

[VK] The Tempest in Brno (directed by Z. Černín, 2005) looked very spectacular, mysterious, miraculous - as the text commands. The spontaneity of the characters was impressive, and especially the tattooed Caliban resembling New Zealand Mãori natives did catch the audience's attention.

[JD] They did Caliban's make-up based on a photo for an hour and a half. The basis of the stage design was as follows - it is not enough to just indicate the storm at the beginning. It is the only and the big change to show Prospero's miracle. I always, when my watercolors were dirty from India ink and I was washing the brushes, used to pour out the dirty water in my bathroom. I poured it out into the sink, washed it all and took out the plug. And that was the moment. The basis of the stage design was in the whirl of the draining black water. This is the hole, from which Caliban then climbs. And it is actually the funnel, in which everything takes place. 
[VK] But there were also historical costumes.

[JD] I love that something is proven guilty of being something else. I really like the contradiction of miracle and reality. Instead of ancient allegory, I had Prospero show everyone the vision of paradise. So, there were twelve beautiful young naked people. It caused terrible problems, especially by the puritans, who ruled the culture in Brno.

I saw King Lear as a movie and was fascinated by it. The contrast of it beginning as a fairytale but then they are fighting in the mud, I was never able to accomplish something similar on the stage, unfortunately. I did it with Ota Ševčík in Pilsen (1988).

[VK] Even though you did it only once, you often interestingly talk about it with your students.

[JD] I dearly love the text, it really is my favorite play because it goes up to the hilt. Lately I realise that I've never suspected that aging is such an adrenaline sport.

But I designed The Dresser (R. Harwood, for the Theatre Without a Balustrade), a story, in which Shakespeare's King Lear is performed during Luftwaffe's air raids in England. I used the scenery as if in the performance when, during an air raid of Hitler's bombers, the scenery falls down with the so-called 'wind'. The scenery was hung on ropes so that it fell very slowly, only blowing the dust into the auditorium. I loved this effect very much, the audience watching the scenery slowly falling down. I know this from the times when I worked as a stagehand. When the scenery was being dismantled, it was always left falling 'with the wind'.

[VK] I think that you yourself never staged Richard III but I heard you describing this dramatic figure to students based on your own experience with the famous 1955 movie.

[JD] Indeed I've never done Richard III. But actually, I encountered the play during the entrance exams for Professor Tröster. The stage design was not really a problem; but then I had to draw a costume: So I drew Richard. And no matter how I drew him, it was always Lawrence Olivier. I put all these drawings aside. Olda Smutný approached me and said: 'Why are you putting these aside?' And I said: 'Because it is Lawrence Olivier.' And Smutný said: 'Put it in; it will be liked...'

[VK] The last time you met Shakespeare on stage was from a somewhat different angle. Last November, Shakespeare in Love by Tom Stoppard premiered in the Palmovka Theatre (2017).

[JD] There was one major problem I had to deal with. It is literally as in our Czech nursery rhyme: In front of the curtain or behind the curtain no one shall stay otherwise I will not play.1 So the stage needed to be changed constantly. I needed many entrances, I would need a door etc. In the foundations of everything eventually was

1 The original „Před oponou za oponou nikdo nesmí stát, jinak nebudu hrát“ is a nursery rhyme used by Czech children when playing hide-and-seek. As it however describes a key to the stage design being discussed, the translator did not attempt to find an equivalent in English because the descriptive quality of the nursery rhyme would be lost. 
ordinary scenery with the usual construction, which is highlighted so it resembles halftimbered walls from the outside. It is not clear where the entrance is, everything can be an entrance, a panel or something with a different meaning. There is a curtain in the middle, which opened and closed in order to make space for actors' action.

[VK] And who is Shakespeare for you then?

[JD] Shakespeare is never straightforward. When you read him you almost think that it's clear and then he always lets you swallow the bait. I remember when Jan Vladislav translated The Sonnets. Simply magnificent. There are amazing verses. For example, how to interpret the line: 'I do forgive thy robbery, gentle thief, although thou steal thee all my poverty'. I like Jan Vladislav's translation of The Sonnets the best. I was a friend of his, we lived not far from each other. When I was working late, I always, when I ran out of cigarettes, looked to see if he had his lights on... and we've often talked.

What fascinates me about Shakespeare is that he can be read over and over because one is always in a different position with different experience. But in addition to the dramatic texts, it is important that he was a great poet. I've never done it but I was always fascinated by the anti-Semitic play The Merchant of Venice, that's the most beautiful monologue defending the Jews. So, it is the great empathy of this person; and, moreover, nothing is unequivocal and it is still topical. From the brutal anti-Semitic comedy a great personal drama has emerged.

[VK] One reviewer wrote about the above-mentioned Tempest from 2005: What would remain of the play, if there was not Dušek's scenography?

[JD] What would remain is just the genius of Shakespeare. 